\title{
Education quality from the viewpoint of educational process participants and the parties concerned
}

\author{
Yuliya Nadtochiy $^{1 *}$, Yelizaveta Rozanova ${ }^{2}$, Andrey Solovyev ${ }^{2}$, Svetlana Shiryayeva ${ }^{2}$, and \\ Natalya Kazantseva ${ }^{3}$ \\ ${ }^{1}$ University Synergy, Department of State and Municipal Administration, Moscow, Russia \\ ${ }^{2}$ Moscow Pedagogical State University, Department of Theory and History of State and Law, \\ Moscow, Russia \\ ${ }^{3}$ State University of Management, Department of Economic Policy and Economic Measurements, \\ Moscow, Russia
}

\begin{abstract}
The relevance of the study of issues related to improving the quality of education in current realities is not in doubt. One may note a wide range of opinions regarding the content and essence of this concept, its structure, ensuring the quality of the educational process, in particular, in educational institutions of higher education, and understanding of the quality of existing education by the educational process participants (teachers and students) as well as parties concerned (employers, parents, etc.). Improving the quality of education is a multifaceted and continuous process that requires careful attention from the scientific community. The authors consider the main definitions of the concept of quality of education and uncover its content. To study different views on the quality of contemporary education, several surveys of the main participants in the educational process, i.e. teachers and students, were conducted. The authors revealed the opinions of employers and graduates regarding the quality of domestic higher education and, based on these qualities, created a profile of contemporary graduates (young professionals) who have received a highquality education. As a result of the conducted research, the conclusion is confirmed that quality is understood by each person according to their accumulated experience and the subjective idea of this category, and changes according to the requirements that are dictated by society and the state in a particular historical period, as well as depending on the conditions of the surrounding reality (a clear example is a current situation with coronavirus which shows that the main skills for employees are the skills and abilities to perform work remotely, which also become key ones when making a decision by the employer about hiring an employee).
\end{abstract}

Keywords: quality of the educational process, graduates, employers.

\footnotetext{
* Corresponding author: yflnjxbq-7e@yandex.ru
} 


\section{Introduction}

Researchers from different fields of science have paid focused attention to various aspects of quality in human life. Currently, there are a lot of formulations (interpretations) of the concept of quality.

Recently, such a concept as the quality of education has become quite popular. Improving the quality of education, addressing the issues of creating special conditions for the training of specialists, who not only have contemporary knowledge and skills but also actually apply them in practice, is currently the subject of wide discussion.

Various studies dealing with the history of the formation of education in different regions of Russia and various countries, as well as in different periods, are becoming relevant $[1,2]$. Collected scientific material allows identifying the features of the domestic educational system for its further development and improvement, and also contributes to the accumulation of worth-while experience in this area, in particular, helping to modernize education in terms of improving its quality component.

Different interpretations of the concept of quality of education are of interest.

In Federal Law “On Education in the Russian Federation" (Article 2. Basic concepts used in this Federal Law) [3] the quality of education is defined as a "comprehensive description of the educational activities and training of the student, expressing the degree of their compliance with Federal State Educational Standards, educational standards, federal-state requirements and (or) needs of physical or legal entity in whose interests educational activity is carried out, including the degree of achievement of the planned results of the educational program" (Article 2 of the Federal Law of 29.12.2012, No. 273-FZ) [3].

In pedagogical dictionaries, the quality of education is described as:

"- compliance of education (as a social system, process, result) with the diverse needs, interests of personality, society, and state;

- a system set of hierarchically organized and socially relevant intrinsic properties (characteristics, parameters) of the education (as a social system, process, result)" [4].

The concept of education can be viewed from three perspectives: as a system, as a process, and as a result. At that, from the standpoint of compliance of the received education with the requirements of consumers (parties concerned), the quality of education can be considered similarly in three perspectives (Fig. 1).

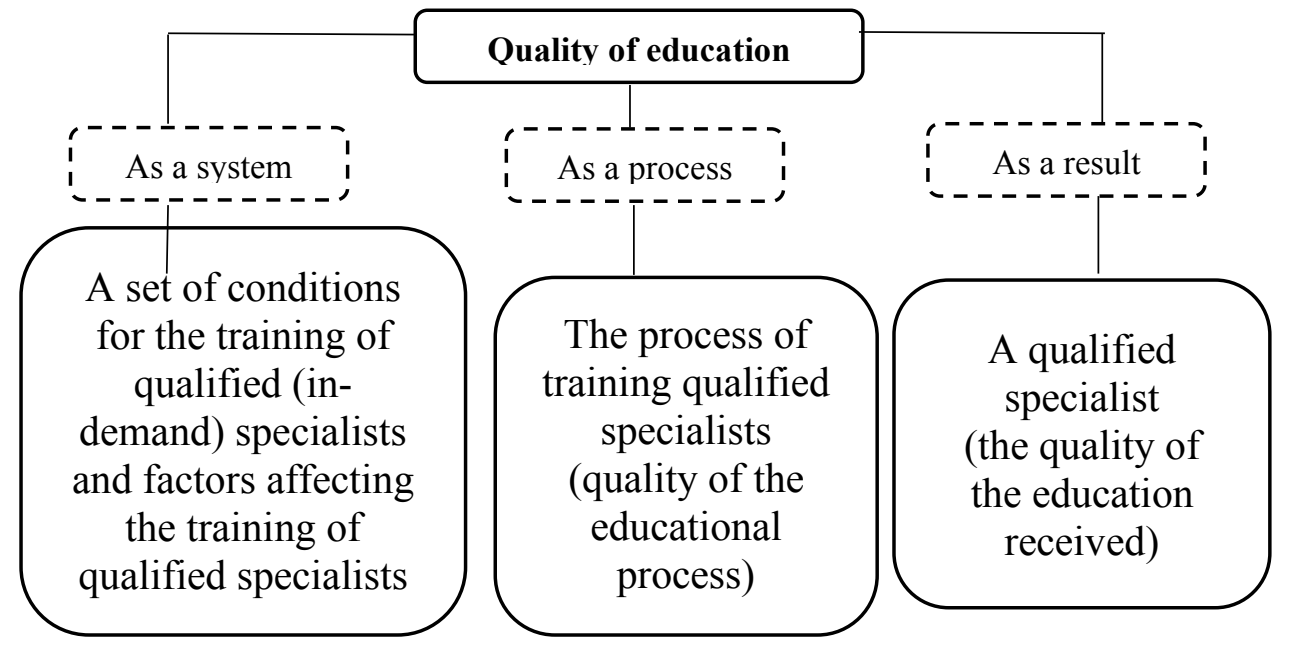

Fig. 1. Education quality structure. 
Some authors distinguish four components of the quality of education (Fig. 2) [5].

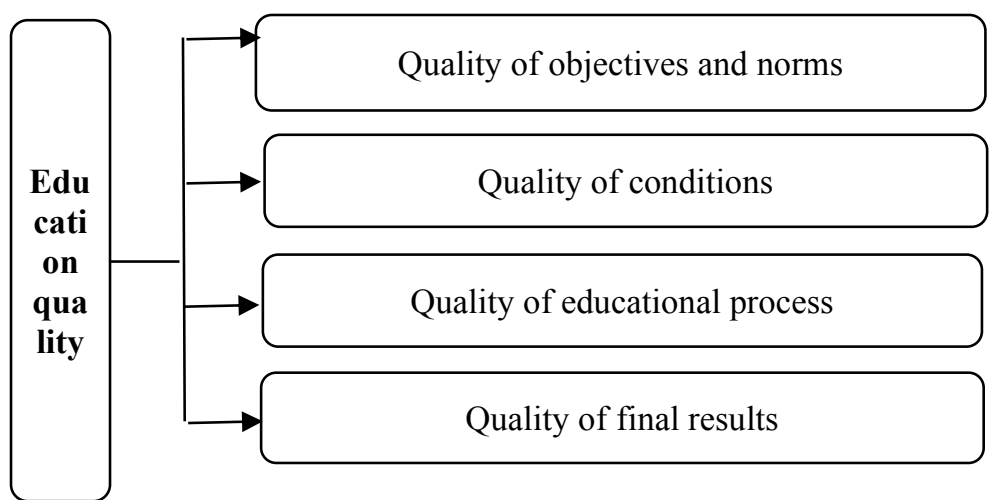

Fig. 2. Education quality.

There is a standpoint that the quality of education is a synthesis of different qualities (Fig. 3) [6].

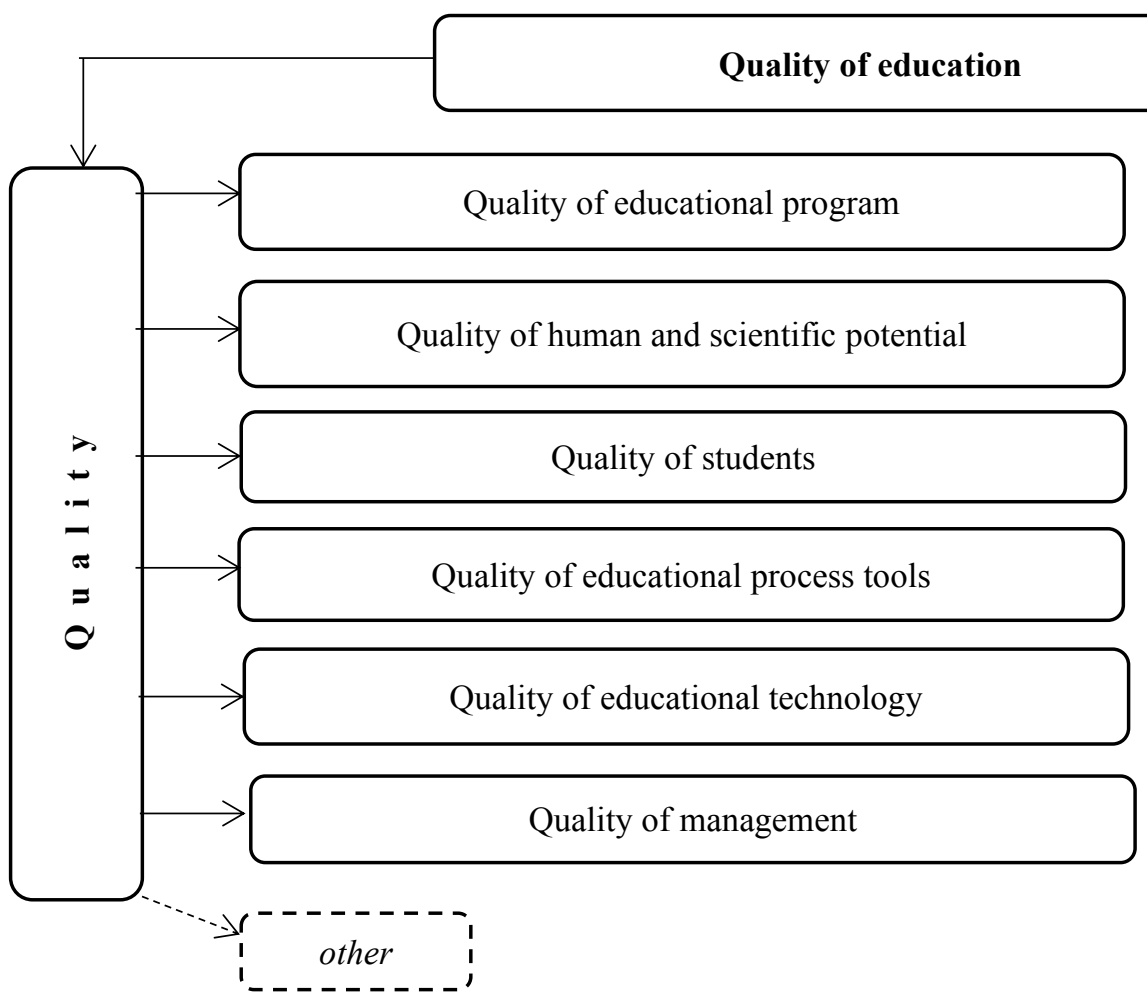

Fig. 3. Education quality components.

Opinions about quality, as well as ideas about this category, are constantly changing. According to the fact that the meaning of quality is defined in standards as the extent to which the consumer demands are met (the degree of correspondence between the aggregate and the inherent characteristics of the requirements), while consumers are either organization or a person receiving the product (service), below are considered the main groups of consumers of educational services (an educational service is a service (product) related to education). 
In general, all consumers can be grouped into two categories:

- external consumers: the state (client), employers, co-workers (if the work is interconnected), the parents (relatives, guardians) of students, alumni (former students), other educational establishments (master's course, postgraduate studies, further education);

- internal consumers: students, fellow students (in teamwork), organizational units of the department (teaching at another department in the master's course), teachers (of other disciplines), staff organization (of academic departments and other organizational units). In line with the definitions given in the standards, external consumers more fit under the category of the party concerned.

The employer evaluates the training of a graduate in two dimensions:

- preparation for solving current problems, knowledge and skills in the specialty, the amount of additional training;

- skills and motivation for self-study throughout the career.

The state (society) evaluates compliance with the needs of the labor market, while the graduate evaluates the educational organization in terms of employment opportunities and further career. Career is considered as a criterion for the quality of educational organization services (Fig. 4) [7].

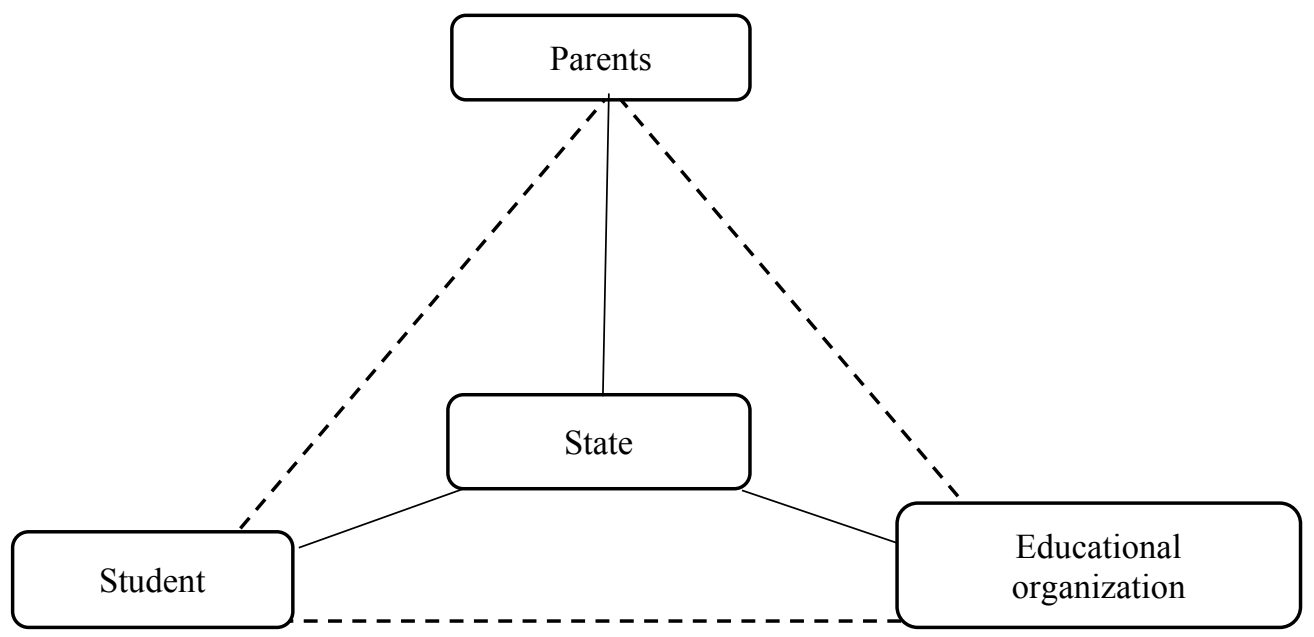

Fig. 4. Consumers of educational organization services.

It is an indisputable fact that each party concerned strives to get high-quality service and, accordingly, meet their needs (as a consumer). In turn, this is necessary to further provide the most concerned party with quality service (product) (as a supplier).

Next, the authors consider how the quality of education is seen by its main participants, i.e. teachers and students, as well as parties concerned, namely, parents, employers, and graduates.

\section{Methods}

In 2019, a mass survey of students of the first to fourth years was conducted at Moscow Institute of Radio Engineering, Electronics, and Automation to study in more detail the opinions about the quality of education from the viewpoint of students (243 people were interviewed). Respondents were asked an open question: "What do you mean by the quality of the educational process?" (one student was allowed giving several answers). Since two main participants can be distinguished in the educational process, namely an educator 
(schoolmaster, teacher) and trainee (student, pupil), in 2020, a survey was conducted (using the mass survey method) of teachers (of educational organizations of higher education and professional educational organizations) and teachers (of general education organizations) of different age categories (from 21 years and older than 80 years) in different cities of the Russian federation. In total, 110 people took part in the survey (the overwhelming majority of respondents were teaching staff of educational institutions of higher education). Teachers were also asked one question "What do you mean by quality assurance in the educational process?" (each teacher could choose from the answers offered, or give their answer) [8].

The survey outcomes of employers, parents, and alumni were carefully analyzed [9-14].

\section{Results}

The overall results of the surveys are illustrated in Figures 5 and 6.

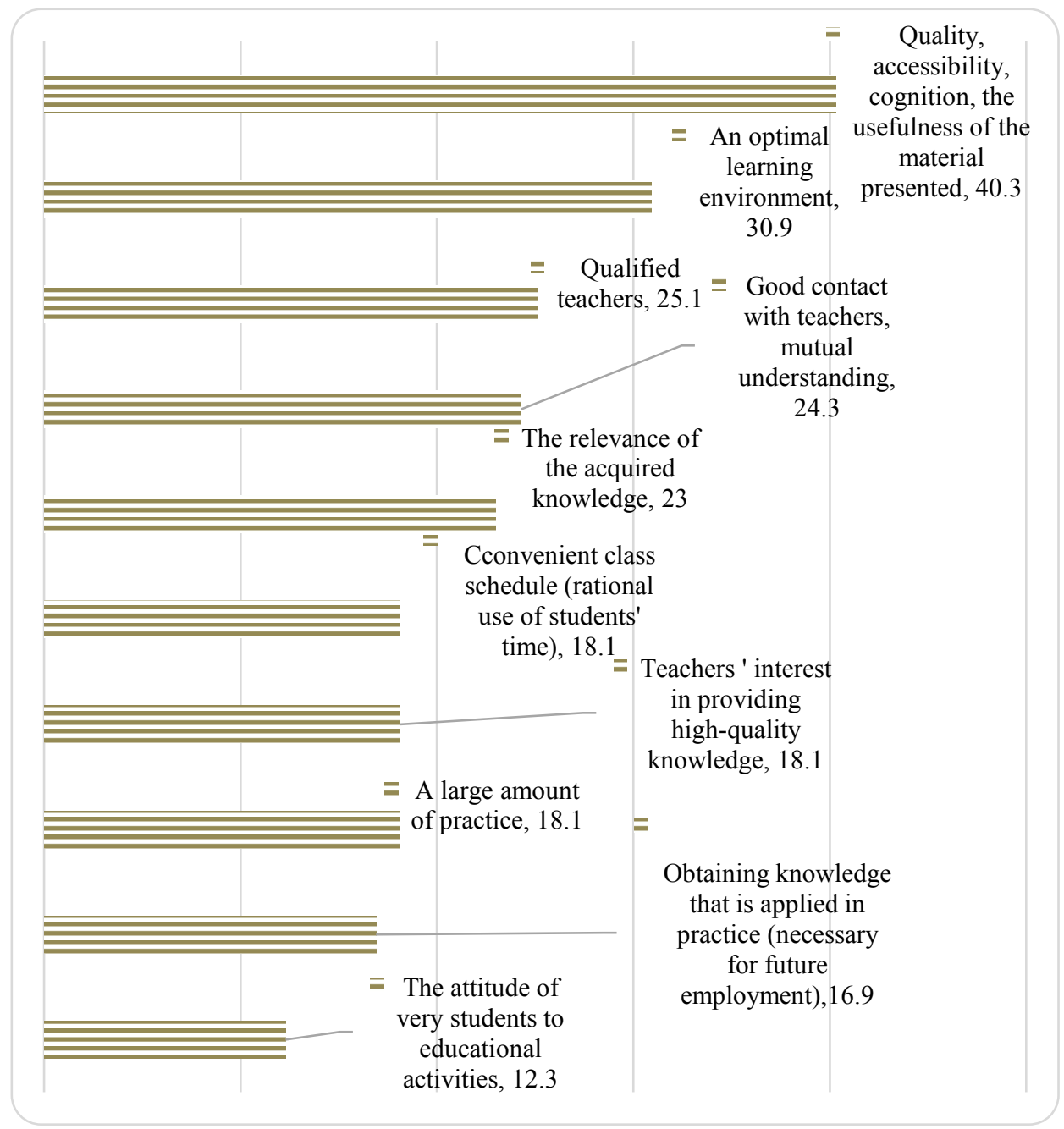

Fig. 5. Overall results of the students' survey (in \% of the total number of respondents). 
$=$ Content of the educational proeess, 46.4

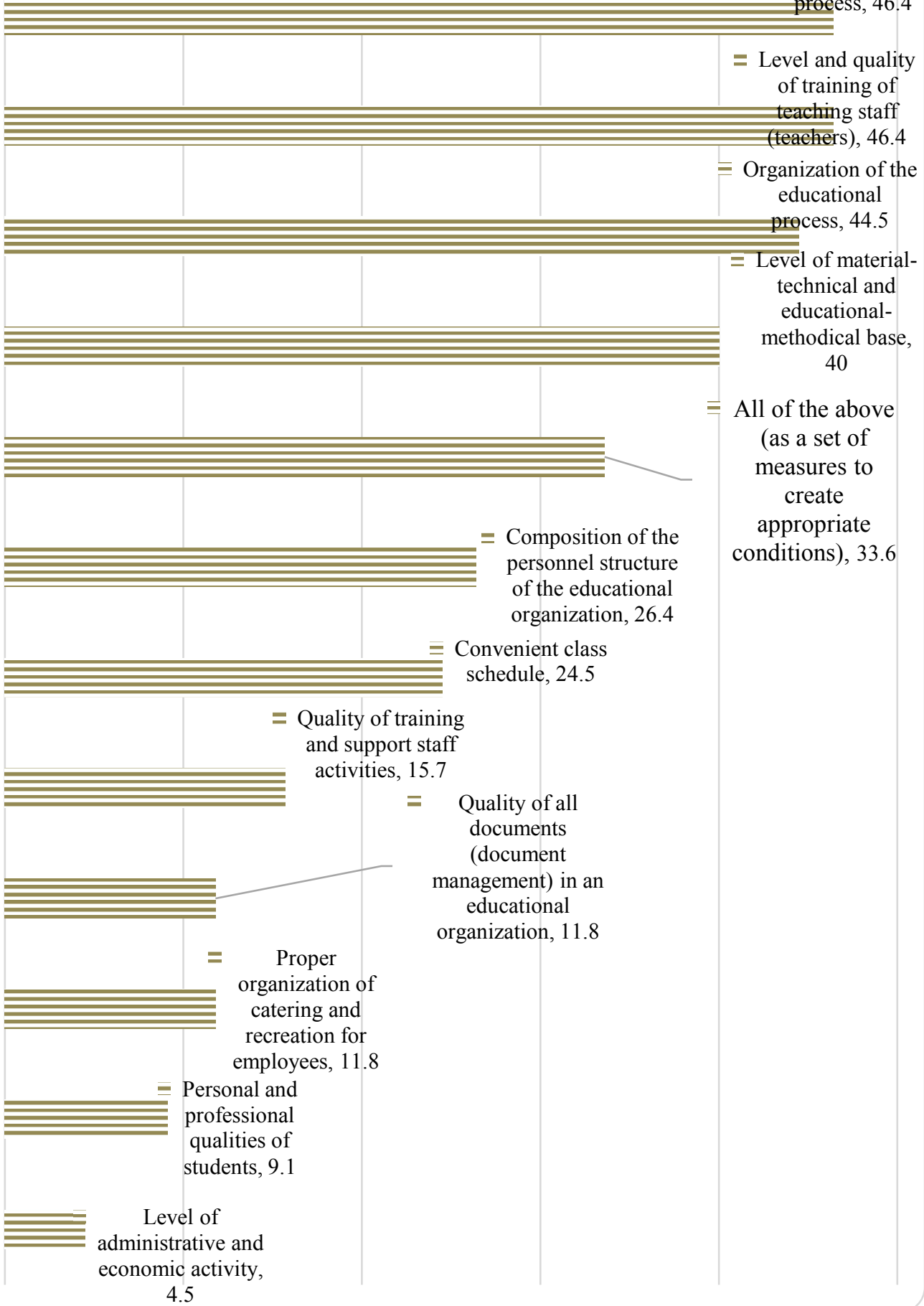

Fig. 6. Distribution of teachers' answers to the question about ensuring the quality of the educational process (in $\%$ of the total number of respondents). 
It can be concluded that for students, the quality of the educational process is cognitive and useful information (40.3\%), optimal learning conditions (30.9\%), qualified teachers $(25.1 \%)$, while for educators (lectors and teachers), ensuring the quality of the educational process mainly consists of the content of the educational process $(46.4 \%)$, the level and quality of teacher training $(46.4 \%)$, and the organization of the educational process $(44.5 \%)$ (Fig. 5, Fig. 6).

For employers, when hiring graduates, the most important qualities are responsibility, (75\%), communication skills $(44 \%)$, diligence $(43 \%)$, and sense of purpose $(40 \%$ of the respondents) [15].

Based on the analysis of data obtained during the interview of employers and students aimed at identifying their views [11, 15-17], the authors composed a profile of a student who has received a quality education, consisting of following qualities:

- responsible, sociable, executing, purposeful employee;

- able to work in a certain area;

- has work-related professional (technical) skills;

- able to solve problems that arise in the course of work;

- able to work independently;

- has organizational skills, able to plan and distribute work;

- observes labor discipline (work schedule, fulfills instructions from management, etc.);

- capable of learning, acquiring new skills;

- able to interact and collaborate with people;

- has a diploma of higher education with honors;

- graduated from a prestigious university ;

- has work experience (practiced) in the specialty;

- shows interest in the work;

- $\quad$ able to work in a team (group);

- has certain personal qualities and skills.

\section{Discussion}

Based on the conducted research, the authors identified the problems that do not contribute to improving the quality of education.

In general, several problems can be identified both at the local (at the level of a specific educational organization) and global level.

One of the main problems of ensuring the quality of education is related to the fact that all participants in the educational process, consumers (parties concerned) have different views on the content of this concept, as well as on its components and characteristics. The question is how to achieve a uniform understanding of the quality concept $[18,19]$.

Currently, one can identify another problem which is ensuring the quality of the educational process in a remote mode (including online learning).

In this regard, in the current situation of transition to distance learning, the results of a mass survey conducted in 2020 are of special interest. The survey was conducted by the Ministry of Education and Science of Russia together with the Institute for Social Analysis and Forecasting of the Russian Presidential Academy of National Economy and Public Administration (RANEPA). The survey, which involved teaching staff of educational institutions, was aimed at the development of the online environment in the context of coronavirus infection.

As the main problems associated with the transition to remote learning, respondents named the problems, such as a decline in students' motivation to study; lack of students' skills and abilities to maintain discipline and diligence in the distance learning, etc. [20]. 


\section{Conclusion}

It is generally accepted that quality requirements are constantly changing. It is known that each person has their idea of quality, which raises the question of how to achieve quality for everyone, how to fulfill the needs of different people and meet their diverse requirements?

Summing up the above, one can draw the following conclusion: to teach qualitatively (the quality of teaching), to provide high-quality educational services, first of all, the teacher himself must receive a high-quality education. It looks like a vicious circle. At that, future teachers must have an opportunity not only to get quality education but also it is necessary for them, as the students, to approach training qualitatively (this concerns, for example, writing a term paper, final qualification work, a thesis, performing tasks of teachers, etc. independently or with teacher's assistance).

\section{References}

1. O.V. Natolochnaya, L.G. Zimovets, R.M. Allalyev, V.A. Svechnikov, European Journal of Contemporary Education, 9(2), 473-480 (2020)

2. O.V. Natolochnaya, V.A. Svechnikov, L.A. Posokhova, R.M. Allalyev, European Journal of Contemporary Education, 9(1), 248-254 (2020)

3. Federal Law of December 29, 2012 N 273-FZ (as amended on 12/08/2020) "On Education in the Russian Federation" (as amended and supplemented, entered into force on 01/01/2021), Article 2. Basic concepts used in this Federal Law, (2020). Accessed on: December 20, 2020. [Online]. Available: https://frf.su/zakon/obobrazovanii-273-fz/st-2.php

4. G.M. Kodzhaspirova, A.Yu. Kodzhaspirov, Pedagogical Dictionary (Publishing Center Academiya, Moscow, 2000)

5. T.I. Shamova, T.M. Davydenko, G.N. Shibanova, Educational systems management (Publishing Center Academiya, Moscow, 2007)

6. S.I. Plaksiy, Higher education: challenges and answers (National Institute of Business, Moscow, 2014)

7. V.A. Lapidus, Quality management in the university. What is this? (SlideServe, 2020). Accessed on: December 20, 2020. [Online]. Available: https://www.slideserve.com/aulani/4903018

8. Yu.B. Nadtochiy, Journal of Advanced Research in Law and Economics, 10(4(42)), 1176-1181 (2019)

9. N.B. Shugal, D.Yu. Migunova, Informatsionnyy byulleten Monitoring ekonomiki obrazovaniya. Information and analytical materials based on the results of sociological surveys (2014)

10. V.D. Orekhov, S.S. Golovchanov, Vestnik Mezhdunarodnogo instituta menedzhmenta LINK, 13(42), 94-100 (2016)

11. N.V. Bondarenko, M.D. Krasilnikova, T.S. Lysova, Assessment of general economic conditions in enterprises and labor demand. Recruitment of graduates of basic professional educational programs in a crisis. News bulletin, 9(98) (Moscow, National Research University Higher School of Economics, 2016)

12. V.N. Rudakov, Informatsionnyy byulleten Monitoring ekonomiki obrazovaniya. Information and analytical materials based on the results of sociological surveys, 16(82) (2018) 
13. Online conference on the topic: Digitalization of the labor market, The official site of the All-Russian Public Opinion Research Center JSC, VTSIOM (n. d.) Accessed on: December 20, 2020. [Online]. Available: http://www.wciom.ru

14. On the quality of Russian higher education. Do you need a higher education to be successful and earn a lot? Materials of the site FOM, (2016) Available at https://fom.ru/Nauka-i-obrazovanie/14436

15. Grades are not important: employers told what graduates they were looking for to work, Materials of the site of ANO, Russia - a country of opportunities (n.d.). Accessed on: December 20, 2020. [Online]. Available: https://rsv.ru/news/1/1267/?mView=detail

16. V.N. Rudakov, Informatsionnyy byulleten «Monitoring ekonomiki obrazovaniya». Information and analytical materials based on the results of sociological surveys, 13(79) (2018)

17. V.D. Orekhov, O.S. Prichina, Ye.S. Shchennikova, Economic Problems and Legal Practice, 1, 43-46 (2018)

18. T.M. Polkhovskaya, Kachestvo i zhizn, No. 4-S(12), 37-45 (2016)

19. V.A. Pukhalsky, Standards and quality, 4, 32-35 (2018)

20. Teachers expressed their opinion about the forced transition of the educational process to online, Informio (Press Service of the Ministry of Education and Science of Russia, 2020). Accessed on: December 20, 2020. [Online]. Available:

https://www.informio.ru/news/id21031/Prepodavateli-vyskazali-svoe-mnenie-ovynuzhdennom-perehode-obrazovatelnogo-processa-v-onlain

21. Interstate standard GOST ISO 9000-2011 Quality management systems. Basic Provisions and Dictionary, Electronic Fund of Legal and Normative and Technical Documentation (n. d.). Accessed on: December 20, 2020. [Online]. Available: http://docs.cntd.ru/document/1200093424 